ISSN 1816-6075 (Print), 1818-0523 (Online)

Journal of System and Management Sciences

Vol. 11 (2021) No. 1, pp. 97-123

DOI:10.33168/JSMS.2021.0107

\title{
Employer Attractiveness and Employee Performance: An Exploratory Study
}

\author{
Minh Ha Nguyen ${ }^{1}$, Nguyen Vinh Luan ${ }^{1}$, Bui Thanh Khoa ${ }^{2}$ \\ ${ }^{1}$ Ho Chi Minh City Open University, Vietnam \\ ${ }^{2}$ Industrial University of Ho Chi Minh City, Vietnam \\ ha.nm@ou.edu.vn; luannv.16ab@ou.edu.vn (correspondingauthor); buithanhkhoa@iuh.edu.vn
}

\begin{abstract}
Improving employee performance always receives researchers and organisational managers' attention as this factor contributes directly to the organisational competitive advantage. Therefore, academic researches, as well as practices, focus on the factors affecting employee performance. However, employer attractiveness, primarily defined as the benefits of an organisation perceived by potential candidates, has not received sufficient attention. Studies regarding employer attractiveness have emphasised on the potential candidates, rather than current employees. Therefore, this study focuses on discovering a new direction - the impact of employer attractiveness on current employees, namely, employee performance. The research method used in this study is the mixed method, especially PLS-SEM analysis tool. Research data is collected from 937 employees from 37 organisations and enterprises in Vietnam. Research results discover the statistically significant relationship between employer attractiveness and employee performance. The results have helped confirm and develop the employer attractiveness factor; especially the new safety value factor.
\end{abstract}

Keywords: Employer attractiveness, employee performance, employer branding. 


\section{Introduction}

In addition to market size and customer loyalty (Khoa at el., 2020), business success is also measured by corporate management's success, especially in human resource management. Employee performance, how an employee performs their tasks, is measured by comparing the task performance to job requirements including the actual performance (leadership, time management, labour productivity) (Betaubun et al., 2015). In other words, employee performance is the value chain of the employee's contribution to the organisation's goal, regardless of whether the contribution is positive or negative (Harwiki, 2016; Nguyen \& Khoa, 2020). According to Sok and O'Cass (2011), employee's contributions are quantified to comprise other relevant factors. That employee performance is defined as the organisation's ability to perform the skills (quality, efficiency and other related factors at work). It is an especially important and necessary factor because of each employee's ability to task performance (Masakure, 2016). In the more detailed approach, Welbourne et al. (1998) assumed that employee performance depends on the five key employee roles: job, career, innovator, team and organisation; in which: job refers to job implementation description for each individual, career refers to the skill implementation essential in organisational progress, innovator refers to work creativity and innovation, the team demonstrates working ability among other colleagues and team members to achieve the company's success, organisation implies how the employee cares about the organisation's goals. Besides, Nguyen and Ngo (2020) also discovered the positive impact of psychological capital on employees' work performance. Moreover, Nguyen et al. (2019) also studied the impact of job crafting on work engagement and work performance.

Unlike employee performance, employer attractiveness is differently defined as follows. First, employer branding is marketing-like branding for a product or company (Ambler \& Barrow, 1996) or a communication form (Bergstrom et al., 2002) or management process (Gatewood et al., 1993) or psychology (Jurgensen, 1978; Collin \& Steven, 2002) or about employee behaviour (Soutar \& Clarke, 1983). The current widely accepted and used concept is developed by Berthon et al. (2005): Employer attractiveness, the benefits of an organisation perceived by potential candidates as the best place to work, includes five dimensions: interesting value, economic value, social value, developmental value and application value. Following the definition of Berthon et al. (2005), employer attractiveness has also been extended to the existing employee object. Employer attractiveness is the perceived level of both potential employees and current employees about the organisation's competitive advantages; in which, the organisation is seen as the best place to work. It will create a long-term and sustainable competitive advantage for enterprises (Jiang \& 1le, 2011). Employer attractiveness is divided into Internal employer attractiveness as the extent to which current employees feel attracted to the organisation they are working for whereas External employer attractiveness shows 
how attractive the organisation is to potential candidates (Pingle \& Sharma, 2013). In terms of the research stream of the employer attractiveness, employer attractiveness focuses on a potential employee, rather than the current employee. Some studies on the impact of employer attractiveness on potential candidates' applying intentions are listed as Sivertzen et al., 2013; Ha \& Luan, 2018). Besides, the effect of employer attractiveness is studied on organisational satisfaction and identity (Bodderas et al., 2011). The completely different study is performed on understanding the branding factors of employers in SMEs (Tumasjan et al., 2011). The number of studies on the effect of employer attractiveness on current employees is very limited. Therefore, this study aimed to explore in-depth to clarify the impact of employer attractiveness on employee performance.

\section{Literature Review}

The person - organisation fit theory, developed by Kristof (1996), deals with antecedents and consequences for the organisation and the organisational individuals. This theory affirms that: to achieve a high level of person - organisation fit through recruitment and socialisation maintains a flexible condition in the organisation's difficult situations. This theory aims to clarify and distinguish between supplementary and complementary fit. The supplementary fit occurs when a person has 'supplements, embellishes, or possesses characteristics' or other characteristics similar to another individual in the working environment. This is different from the complementary fit; a person's personality is 'made whole' on the environment (Muchinsky \& Monahan, 1987). In another explanation, the personorganisation fit is provided from needs-supplies and demands-abilities (Edwards, 1991). If the analysis from the needs-supplies perspective, the person-organisation fit will occur when the organisation satisfies the individual's needs and expectations. On the contrary, the person-organisation fit will occur from the demand-abilities direction when an individual meets its working capacity requirements.

Employer branding theory is based on the combination of marketing principles and human management. This concept is seen as the package of both economic and psychological benefits provided to employees from their organisations (Ambler \& Barrow, 1996). Wally (1989) identifies that employer brand is the first way to create an organisation's organisational culture and inner spirit in the previous different approach. These results increase the motivation of the entire organisation to connect with the employee. Besides, the organisation's reputation will be created for all stakeholders (Hlavsa et al., 2015). Another foundation of the employer branding theory is the psychological contract theory that deals with the relationship between the organisation and employees. According to Hendry and Jenkins (1997), the psychological contract concept between employees and companies in the traditional view is the exchange of benefits between the two sides. Accordingly, the employee will commit to being loyal to the company in return for job safety. However, the 
changing trends in the current period (downsizing, outsourcing and flexibility, psychological contracts) transformed in a new form. Specifically, the company will provide the employee with the necessary working skills through training and development in return for their efforts (Baruch, 2004). In additionally, in terms of newcomers' negative perceptions, the company can use employer branding to promote the benefits they can provide to the employee (training, career path and personal development). In other words, once a company has trouble finding an employee's solution, the employer branding strategy can be designed to change company perceptions (Newell \& Dopson, 1996; Hendry \& Jenkins, 1997).

According to the original concept of employer branding, Ambler and Barrow (1996) defined three dimensions as employer identity: psychological, functional and economical. Based on this background, Berthon et al.(2005) researched to develop three dimensions of employer attractiveness into five dimensions: interest value, social value, development value, application value and economic value. Economic benefits represent the economic value, while the psychological benefits are separated into interest value and social value. Besides, functional benefits are broken down into development value and application value. It showed that, according to the reflective model, the employer attractiveness would have a positive impact on each of its dimensions. Following that, Arachchige and Robertson (2013) based on previous research and survey results of business students and employees who worked for businesses in Sri Lankan, developed eight dimensions of employer attractiveness includes Job structure, Social commitment, Social environment, Relationships, Personal growth, Organisational Dynamism, Enjoyment, and Corporate environment. The research results showed a strong similarity between the perception of the two groups of students and the experienced employee about the attributes of the employer attractiveness. Job structure and Enjoyment have content similar to interest value; Social commitment is similar to economic value, social environment will be similar to application value, relationships, personal growth and corporate environment factors like social value, organisational dynamism will be similar to the development value (Berthon et al., 2005). In another study, Roy (2008) developed additional employer attractiveness dimensions in India's research context. Accordingly, there are two content that this author added is ethical value and career opportunity. Specifically, Roy (2008) developed the employer attractiveness scale including eight factors: Application Value, Interest Value, Ethical Value, Economic Value, Social Value, Psychological Value, Career Opportunities, and Development Value.

Meanwhile, Gadibadi (2020) developed two more interesting dimensions related to startup cases, which are entrepreneurial and Challenge. The dimension "entrepreneurial" shows development opportunities based on performance evaluation, taking on different roles, and building a knowledge base through startup activities. Particularly dimension "challenge" shows challenging, attractive jobs and 
high level of responsibility and authorisation. Besides, through qualitative and quantitative research to develop and confirm the employer attractiveness scale, this study added a dimension, safety value. This factor reflects the extent to which an individual is attracted to job security (Berthon et al., 2005). According to Lazorko (2019), job security is an important factor that can be communicated to attract employees. In other words, employer attractiveness will have a positive impact on safety in an organisation.

Furthermore, Herman and Gioia (2001) also argued that one employer branding criterion is safety value. Employer attractiveness will have a positive impact on the safety value of businesses' operations. In summary, the five dimensions model of employer attractiveness by Berthon et al.(2005) and safety value (added dimension) has been widely used in studies on employer branding (Roy, 2008; Reis \& Braga, 2016; Sivertzen et al., 2013; Biswas \& Suar, 2013; Kaur et al., 2015; Arachchige \& Robertson, 2011; Ha and Luan, 2018). Therefore, employer attractiveness was identified, including the following five factors: social value, development value, application value, safety value and economic value.

For employee performance, there are many definitions and scales of these factors, including measures of leadership, time management, productivity (Betaubun et al., 2015), behaviour (Harwiki, 2016), quality, effectiveness and other relevant effects (Sok \& O'Cass, 2011). However, this study used key elements of Welbourne et al.(1998) to build key employee performance dimensions, including teamwork, innovator and job. First, for teamwork, Borman \& Motowidlo (1997) and Campbell (1990) argue that many studies on performance models have teamwork factor as an important component. Many researchers have confirmed that awareness of the role of teamwork and its use in organisations has increased in recent years (Stevens \& Campion, 1994). Furthermore, the compensation theory has clearly shown the importance of teamwork in the organisation through gainsharing plans. The implementation of gainsharing is seen as the activity of distributing financial benefits of the business to the entire organisation. Studies have shown that gainsharing plans and team-related rewards help align members to an organisation (Welbourne \& Cable, 1995). In other words, the payroll system encourages cooperation among members and between teams. Therefore, the teamwork factor is very important when evaluating an employee's performance. Secondly, dimension innovator is also an element of employee performance. A company can only maintain its competitiveness once its employees can be creative in their overall operations (Schein, 1980; Khoa \& Thai, 2021). People need to have an innovative methodology to apply in their work and contribute to business performance (Van Maanen \& Scheiri, 1979; Khoa, 2020). In summary, the innovator is important not only for large firms but also for small firms (Gomez-Mejia \& Balkin, 1992). Finally, the job factor is also a very important component. In the previous studies, the job and organisation roles were defined as a dimension of work performance. From a 
traditional perspective, the job is seen as a component of employee performance. Alternatively, in other words, each member's role in an organisation must be similar to those associated with organisational citizenship behaviours (Organ, 1988). Besides, Welbourne and Cable (1995) have proven the jobholder role and each member's role in the organisation. The employee needs to implement both roles in the working organisation. Furthermore, the job role is supported by the compensation system. Thus, it can be seen that the job is an essential component of employee performance. Based on the above, this research has built employee performance components, including the following three dimensions: Teamwork, Innovator and Job.

\section{Hypothesis and the research model}

\subsection{Hypothesis}

According to Berthon et al. (2005), social value factors attracting employees that organisations can perform are a happy working environment, fun, friendliness and teamwork spirit. According to person-organisation fit theory (Kristof, 1996), companies can provide employees with their needs, including finance, physic, psychology, and development opportunities. On the contrary, the employee will provide their values to the company, including effort, commitment, time and knowledge. Therefore, this is a harmonious relationship. Combining this theory with the concept of social value by Berthon et al. (2005), the company will provide social values to attract employees (a friendly, funny, happy and good teamwork environment). According to the person-organisation fit theory, these values are similar to psychological factors (Kristof, 1996). When the employer meets the employee's needs, harmonious relationship-improving employee performance will be created. Therefore, the social value of employer attractiveness positively impacts employee performance because the work environment is an important factor in employee productivity. A good environment will allow employees to work in the best way with willingness, interaction, creative cooperation, and employees' satisfaction (Gonzalez, 1999) to improve employee work efficiency (McGuire \& McLaren, 2007). If an organisation maintains a good working environment, the employee's productivity will increase. In summary, environmental factors and social value play a very important role in the organisation. Labour productivity or performance will be increased due to the working environment (Awan \& Tahir, 2015).

Developmental value reflects that a potential candidate is attracted by the recognition, confidence and working experience underpinning career development (Berthon et al., 2005). According to person-organisation fit theory (Kristof, 1996), the relationship between employer and employee depends on harmonious standards. The employee contributes to the company once he is provided with resources (salary, bonus and perspective). Concurrently, the employee will contribute to the 
employer's values (knowledge, skills, and experience). Employee's contribution action will create the employee's working efficiency. In other words, the higher the harmonious relationship between employer and employees reaches, the better the effect of the impact on the work performance of the organisation becomes. According to Tziner (1987), the person-organisation fit leaves a long-term impact on employees' work efficiency, whereas Berthon at el. (2005) believes that developmental value will give the employees opportunities to create confidence and experience for future development to attract employees. This developmental value is similar to the employer's resources to the employees in the person-organisation fit theory (Kristof, 1996). Hence, developmental value has a positive impact on employee performance. Awan \& Tahir (2015) also argued that the employer providing training and skill development programs and recognising employee contributions helps build a good working environment, leading to a positive impact on employees' efficiency and labour productivity. When the employees get a quality-training program, they will improve assigned tasks (labour productivity, working efficiency) (Farooq \& Khan, 2011). Besides, Muzaffar et al. (2012) demonstrated that staff training and development activities, as intangible assets of each organisation, contribute to improving the employee's multiple skills and maintaining the employee and its competency systems. Besides, activities create harmony and uniformity between individuals and organisations to maintain diverse human resources skills and work efficiency. Based on the above theories and studies, developmental value is concluded to impact employee performance positively.

Application value shows that potential candidates are attracted by the opportunities to apply their knowledge to work and teach others, reflecting humanistic and customer-focused orientation (Berthon et al., 2005). According to person-organisation fit theory (Kristof, 1996), the relationship between employer and employee is mutually supportive. In particular, employees need to provide their values (experience, knowledge, time, effort, commitment and abilities such as tasks, interpersonal) to the employer. In contrast, the employer will provide employees with employer resources (financial, physical, and psychological, task-related, interpersonal and development opportunities). When the communication achieves the level of harmony, it is known as achieving the person-organisation fit state. The benefit of the person-organisation fit state is improving employee performance (Tziner, 1987). Besides, application value includes creating opportunities for employees to apply their knowledge to work and teaching colleagues (Berthon et al., 2005). This value's content is similar to that of interpersonal in the personorganisation fit theory (Kristof, 1996). If combining the theory and definition of application value, application value positively impacts employee performance.

Furthermore, each member's knowledge management will positively impact employee productivity (Drucker, 1998; Drucker, 1999). According to knowledgeemployee productivity theory, to improve labour productivity, an organisation can 
implement the following solutions to continuously training, teaching employees, authorising work, working with requirements that demand both quantity and quality, awareness of knowledge as an asset, job/tasks based on knowledge. Besides, knowledge-employee productivity theory comprises knowledge management systems, knowledge management processes, knowledge management infrastructure and other related things (Kianto et al., 2016; Kivipõld, 2015; Tseng \& Fan, 2011). In short, knowledge management will have a positive impact on the creativity of the organisation. The employee can create and use knowledge effectively bypassing engagement with the organisation's knowledge management implementation. Accordingly, employees can use knowledge to create benefits when performing jobs in the most creative, efficient and fast manner (Tseng \& Fan, 2011; Nonaka, 1994). Furthermore, Tseng and Fan (2011) also demonstrated that knowledge management impacts job performance. Application value is implied to have a positive impact on employee performance.

According to Berthon et al.(2005), the safety value factor shows that the organisation's job security attracts an employee. Kartikasari (2017) found the impact of OSH security facilities on employee performance. In particular, safety factor, considered a good factor, protects employee in case employee has an accident, illness or a dangerous problem at work and life. Several companies have used a hospital or healthcare centre's service to support this activity to feel more confident in unexpected situations. Simultaneously, once employees feel more secure at work, they will focus more on their work and ensure work efficiency is more guaranteed. Sharing this view, Hasibuan (2008) argued that all direct corporate efforts would help maximise employee performance. Besides, Permanasari (2014) discover that job safety factor will positively impact employee performance. Brown and Leigh (1996) find that psychological safety helps improve job involvement and performance. Because psychological safety will ensure that the company's work environment is where employees can interact freely and reliably, this favourable condition is for employees to share their ideas without fear of punishment or criticism (West, 1990). Indeed, once employees have a good and safe working environment, they implement proposals, develop and present new ideas, increase their ability to learn and foster creativity, and create positive work behaviours, leading to better working efficiency. This result has received much support and agreement from other researchers. When an organisation provides psychological safety for the employee, it will receive better working efficiency. Safety is important at the individual level and at the team and organisation level (Thamhain, 2003; Baer \& Frese, 2003; May et al., 2004; Janssen, 2004). Furthermore, recent empirical studies have shown that high-level psychological safety enhances employees' creativity, learning and engagement (Lyu, 2016; Edmondson, 1999; West \& Andersen, 1996).

The economic value indicates the degree to which organisations provide potential 
candidates with higher wages, benefits, insurance and promotion opportunities to attract them to work (Berthon et al., 2005). According to the person - organisation fit theory (Kristof, 1996), the relationship between employer and employee is a harmonious one based on fairness. Accordingly, the employer will provide employees with resources, including values related to financial and economic factors. On the contrary, the employee will give the employer back values (time, effort, commitment, experience and capabilities, including tasks, interpersonal); therefore, leading to increased employee performance. Moreover, financial and economic values will positively impact employee performance (Tziner, 1987). In another aspect, employee satisfaction is considered one important factor in increasing employee's motivation to work. Next, their work motivation will directly affect their work effort. Work motivation includes both internal and external factors (Herzberg et al., 1959), in which salary and bonus is the oldest and most important factor as an effective tool to help employees and their families stabilise their life. Therefore, managers need to ensure that excellent employees are rewarded in the form of increased salary. Employee motivation will benefit the company by bringing about changes and helping the business grow. The management of compensation is a function of personnel management about salary and bonuses that employees will receive when performing team duties (Ivancevich, 2003). Salary and bonuses will help change an employee's work effort (Milkovich \& Newman, 1999). In other words, compensation is a way of distributing economic benefits to employees' work efforts (Bhattacharyya, 2007). Compensation is provided to the employee to improve work efficiency and ensure this benefit is controlled at a reasonable cost (Cassandro, 2008). In summary, the theory and previous studies can imply that economic value is one explanatory variable for employee performance (Sajuyigbe et al., 2013; Ojokuku \& Sajuyigbe, 2009; Peretomode \& Peretomode, 2005).

Based on the above reasons, the hypothesis is proposed as following:

H1: Employer attractiveness has a positive impact on employee performance.

\subsection{The research model}

According to the concept and scale of employer attractiveness factor developed by Berthon et al. (2005) and those of employee performance developed by Welbourne et al.(1998), the study builds the model measurement from the resulting model (Reflective, Mode A). Besides, according to the research hypothesis, employer attractiveness is expected to impact employee performance positively. Therefore, the proposed research model, according to Figure 1, is as follows: 


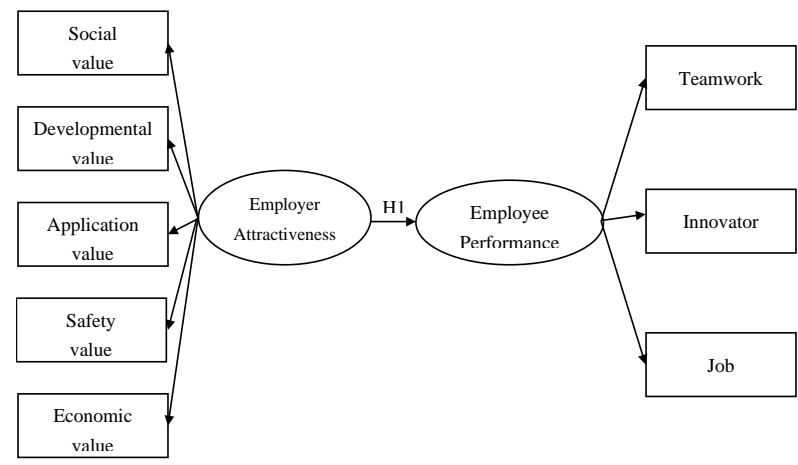

Fig. 1: The research model.

\section{Research Methodology}

This research used was a mixed method of qualitative research and quantitative research. Firstly, the scale adjustment and development is conducted by qualitative research method. Next, to evaluate the scale's reliability, validity and test research hypotheses, this study used quantitative research methods. The data collection methods were used in qualitative research, including expert interviews and focus group discussion. The expert interview was conducted with four lecturers with a deep understanding of marketing and human resource management. At the same time, these professionals also have much experience in corporate management activities. In focus group discussions, the participants will include employees who have worked for at least five years to understand the company's employer branding activities to contribute opinion about the survey questionnaire scales. For the quantitative research method, the study uses SPPS and PLS-SEM software. Analytical phases assess the measurement model and the structural model. Data collection is performed through the survey questionnaires sent directly to the respondents. After being answered and collected from the respondents, the survey data will be screened and reviewed to choose which questionnaires meet the research requirements. The number of respondents who answered the research satisfactory was 937 people from 37 enterprises and Vietnam organisations. Table 1 shows the demographic information of the sample. 
Table 1: Descriptive statistics results

\begin{tabular}{|c|c|c|c|}
\hline No. & Content & Frequency & Percentage (\%) \\
\hline I & Gender & & \\
\hline 1 & Male & 471 & 50.3 \\
\hline 2 & Female & 466 & 49.7 \\
\hline II & Married Status & & \\
\hline 1 & Single & 381 & 40.7 \\
\hline 2 & Married & 556 & 59.3 \\
\hline III & Age & & \\
\hline 1 & From 18 to 30 & 491 & 52.4 \\
\hline 2 & From 31 to 40 & 349 & 37.2 \\
\hline 3 & From 40 to 50 & 83 & 8.9 \\
\hline 4 & From 50 to 60 & 14 & 1.5 \\
\hline IV & Qualification & & \\
\hline 1 & Unskilled & 27 & 2.9 \\
\hline 2 & Intermediate & 180 & 19.2 \\
\hline 3 & Colleges & 160 & 17.1 \\
\hline 4 & University & 464 & 49.5 \\
\hline 5 & Graduate & 106 & 11.3 \\
\hline $\mathrm{V}$ & Job & & \\
\hline 1 & Production/Technical/RD & 347 & 37.0 \\
\hline 2 & Business & 229 & 24.4 \\
\hline 3 & Back Office & 361 & 38.5 \\
\hline & Total & 937 & 100.0 \\
\hline
\end{tabular}

The scale of all research concepts in this study was based on the previous studies and qualitative research results. The scales used the 5-pointed Likert scale from (1) Total disagree to (5) Total agree. In which, employer attractiveness scale was based on the scale of Berthon et al.(2005) including five factors (social value, developmental value, application value, safety value, and economic value) and the scale of employee performance was based on the scale of Welbourne et al.(1998), including three factors (teamwork, innovator, and job).

\section{Data Analysis}

\subsection{Scale reliability and validity}

This research tested the reliability of employer attractiveness, employee performance scale measurement through Cronbach's Alpha (CA). Simultaneously, the internal consistency standard of these scales is tested by exploring factor analysis (EFA). In table 2, all scales met the analytical criteria as follows: Cronbach's Alpha of all constructs of employer attractiveness and employee 
performance were greater than 0.8. Based on this result, all items will be kept in these two scales. The KMO values of employer attractiveness and employee performance were 0.948 and 0.931 , respectively. Besides, the significant in Bartlett's test of these scales have a value of $0.000(<0.05)$, proving that these scales meet the standard of exploratory factor analysis (EFA) (Hair et al., 2017). For Total Variance Explained index of the employer attractiveness and employee performance scales, the values of $71.583 \%$ and $65.385 \%$ are respectively greater than $50 \%$ as prescribed. Therefore, this criterion of both scales is satisfactory (Gerbing and Anderson, 1988). The eigenvalue of the employer attractiveness concept (hereafter EA) was 1.024, which showed that the factors include social value (hereafter SOC), developmental value (hereafter DEV), application value (hereafter APP), safety value (hereafter SAF) and economic value (hereafter ECO). The eigenvalue of employee performance concept (hereafter EP) was 1.233, which shows that the factors on this scale, including teamwork (hereafter TEA), innovator (hereafter INO) and job (hereafter JOB). That both of these eigenvalue values were greater than 1.0; hence, the scale meets the standard (Gerbing and Anderson, 1988).

Moreover, two scales have a Composite Reliability (CR) value of greater than 0.70 and an Average Variance Extracted (AVE) value greater than 0.50, and all the employer attractiveness items' outer loading values have a value from 0.688 to 0.913 as well as employee performance has a value from 0.706 to 0.906 , each with a value greater than 0.708 (Hair et al.,2016). The criteria prove that both scales meet convergent validity.

Table 2: Results of scale reliability and convergent validity

\begin{tabular}{|c|c|c|c|c|c|c|c|}
\hline \multirow[b]{2}{*}{ Constructs } & \multirow[b]{2}{*}{$\mathbf{C A}$} & \multicolumn{4}{|c|}{ Explore Factor Analysis (EFA) } & \multirow[b]{2}{*}{$\mathbf{C R}$} & \multirow[b]{2}{*}{ AVE } \\
\hline & & KMO & $\begin{array}{c}\text { Bartlett's } \\
\text { Test of } \\
\text { Sphericity }\end{array}$ & Cumulative \% & $\begin{array}{l}\text { Eigen } \\
\text { values }\end{array}$ & & \\
\hline \multicolumn{8}{|c|}{ Employer attractiveness (Outer loading: 0,688 -0,913) } \\
\hline SOC & 0.911 & \multirow{5}{*}{0.948} & \multirow{5}{*}{0.000} & \multirow{5}{*}{$71.583 \%$} & \multirow{5}{*}{1.024} & 0.931 & 0.694 \\
\hline DEV & 0.902 & & & & & 0.925 & 0.674 \\
\hline APP & 0.832 & & & & & 0.889 & 0.666 \\
\hline SAF & 0.844 & & & & & 0.906 & 0.764 \\
\hline ECO & 0.849 & & & & & 0.908 & 0.767 \\
\hline \multicolumn{8}{|c|}{ Employee performance (Outer loading: 0,706 - 0,906) } \\
\hline TEA & 0.902 & \multirow{3}{*}{0.931} & \multirow{3}{*}{0.000} & \multirow{3}{*}{$65.385 \%$} & \multirow{3}{*}{1.233} & 0.921 & 0.594 \\
\hline INO & 0.898 & & & & & 0.921 & 0.663 \\
\hline JOB & 0.847 & & & & & 0.909 & 0.768 \\
\hline
\end{tabular}


One discriminant validity among the latent variables of employer attractiveness is the Heterotrait - Monotrait (HTMT) standard. Table 3 shows the HTMT values of all observed variables in the matrix. That all values of HTMT are smaller than 0.85 ; hence, the research variables in the model have quite a good discriminant. $2.5 \%$ and $97.5 \%$ of columns show the low and high $95 \%$ confidence interval (the difference between the calibration and cumulative). The confidence interval does not include 1 . These values proved that the employer attractiveness scales achieved discriminant validity.

Table 3: HTMT of Employer attractiveness

\begin{tabular}{|c|c|c|c|c|c|c|c|c|c|c|}
\hline & SOC & DEV & APP & SAF & ECO & & O & Bias & $\mathbf{2 . 5 \%}$ & $\mathbf{9 7 . 5 \%}$ \\
\hline SOC & & & & & & EAàSOC & 0.867 & 0.000 & 0.846 & 0.885 \\
\hline DEV & 0.759 & & & & & EAàDEV & 0.908 & 0.000 & 0.895 & 0.921 \\
\hline APP & 0.654 & 0.773 & & & & EAàAPP & 0.79 & 0.000 & 0.755 & 0.823 \\
\hline SAF & 0.687 & 0.701 & 0.611 & & & EAàSAF & 0.765 & 0.001 & 0.727 & 0.800 \\
\hline ECO & 0.605 & 0.707 & 0.586 & 0.594 & & EAàECO & 0.735 & - & & \\
\hline
\end{tabular}

The study examines the discriminant value among the latent variables of employee performance. Table 4 shows the HTMT for all pairs of variables studied in a matrix means that all values of HTMT are much smaller than 0.85 . The low and high limit of the $95 \%$ confidence interval (the difference between the calibration and cumulative) of all groups of research variables does not contain 1.0. These values assert that employee performance scales achieve discriminant validity.

Table 4: HTMT of Employee performance

\begin{tabular}{|c|c|c|c|c|c|c|c|c|}
\hline & TEA & INO & JOB & & Beta & Bias & $\mathbf{2 . 5 \%}$ & $\mathbf{9 7 . 5 \%}$ \\
\hline TEA & & & & EPàTEA & 0.907 & -0.001 & 0.89 & 0.921 \\
\hline INO & 0.712 & & & EPàINO & 0.873 & 0.000 & 0.852 & 0.891 \\
\hline JOB & 0.650 & 0.649 & & EPàJOB & 0.757 & -0.001 & 0.721 & 0.787 \\
\hline
\end{tabular}

All groups of scale variables of employer attractiveness (including SOC, DEV, APP, SAF and ECO latent variables) and employee performance scale (including TEA, INO and JOB latent variables) achieve internal consistency reliability, convergent validity and discriminant validity.

\subsection{Structural model assessment}

The first criterion in evaluating a structural model is the Multi-collinearity test: This phenomenon occurs when the correlation degree is high among the independent variables in the linear measurement model., the variance inflation factor (VIF) is applied to measure this phenomenon (Akinwande et al., 2015). All VIF values of all 
endogenous variables and the corresponding exogenous variables were 1, which were less than 2 ; therefore, multi-collinearity does not occur in research models.

$\mathrm{R}^{2}$ coefficient is used to measure the research model's appropriateness. The higher value of $\mathrm{R}^{2}$ is, the higher the predictability of the research model becomes. Besides, in multiple regression models, the studies often use adjusted $\mathrm{R}^{2}$ value to avoid the deviation caused by complex models. The values $\mathrm{R}^{2}$ and adjusted $\mathrm{R}^{2}$ for the employee performance are 0.13 and 0.10 , respectively. With these adjusted $\mathrm{R}^{2}$ values, the research model's explanation and prediction levels are low. However, according to Hair et al. (2017), $\mathrm{R}^{2}$ value at 0.2 may be considered high for behavioural studies. Therefore, this value is acceptable due to employee behaviour, although this relationship's adjusted $\mathrm{R}^{2}$ value is relatively low.

Also, to evaluate the $\mathrm{R}^{2}$ value of all endogenous variables, the change in the $\mathrm{R}^{2}$ value (when a particular exogenous variable is omitted from the model) can be used to evaluate whether the omitted variable affects significantly up to endogenous variables or not. This measurement is called the impact factor $\mathrm{f}^{2}$. By the standard, $\mathrm{f}^{2}$ with values of $0.02,0.15$, and 0.35 would represent small, medium, and large effects; respectively (Cohen, 1988). $\mathrm{f}^{2}$ value is less than 0.02 demonstrates no effect. Table 5 shows that EA has an average effect of 0.115 on EP; it showed that EA has an only medium impact on EP.

Table 5: Effect size $\mathrm{f}^{2}$

\begin{tabular}{|c|c|c|c|c|c|c|c|c|c|c|}
\hline & APP & DEV & ECO & EP & EA & INO & JOB & SAF & SOC & TEA \\
\hline EP & & & & & & 3.202 & 1.34 & & & 4.616 \\
\hline EA & 1.649 & 4.666 & 1.187 & 0.115 & & & & 1.416 & 3.012 & \\
\hline
\end{tabular}

In additionally, the $\mathrm{Q}^{2}$ value is used to assess the importance of $\mathrm{R}^{2}$ values to assess the accuracy of the prediction, (Geisser, 1974 and Stone, 1974) as an indicator of the out-of-sample predictive power.

Table 6: Q2 value

\begin{tabular}{|c|c|c|c|}
\hline & SSO & SSE & $\mathbf{Q}^{\mathbf{2}}(\mathbf{= 1 - S S E} / \mathbf{S S O})$ \\
\hline APP & 3748.00 & 2227.77 & 0.406 \\
\hline DEV & 5622.00 & 2528.85 & 0.550 \\
\hline ECO & 2811.00 & 1661.18 & 0.409 \\
\hline EMPLOYEE PERFORMANCE & 15929.00 & 15141.63 & 0.049 \\
\hline EMPLOYER ATTRACTIVENESS & 20614.00 & 20614.00 & \\
\hline INO & 5622.00 & 2810.26 & 0.500 \\
\hline JOB & 2811.00 & 1587.15 & 0.435 \\
\hline SAF & 2811.00 & 1567.89 & 0.442 \\
\hline SOC & 5622.00 & 2714.86 & 0.517 \\
\hline
\end{tabular}




\begin{tabular}{|c|c|c|c|}
\hline & SSO & SSE & Q $^{2}(=1-S S E / S S O)$ \\
\hline TEA & 7496.00 & 3862.88 & 0.485 \\
\hline
\end{tabular}

When PLS-SEM exhibits the predictive relevance, data that is not used in model estimation can be correctly predicted. Regarding evaluation criteria, with the structural model, the value $\mathrm{Q}^{2}$ is greater than 0 for a specific endogenous latent variable, indicating the path model's predictive relationship for this particular dependent variable. From Table 6 , the value $\mathrm{Q}^{2}$ of endogenous variables is greater than 0 through blindfolding result. That employee performance has the value of $\mathrm{Q}^{2}$ of 0.049 suggests that the model's predictive relevance to endogenous latent variables is possible.

Table 7 described the relationship between the research variables and research hypothesis test. That employer attractiveness has a medium positive impact on employee performance $(\beta=0.321)$ with $99 \%$ confidence implies that the hypothesis is supported. Figure 2 pointed out the relationship between the concepts and constructs in the research.

Table 7. Hypothesis testing result

\begin{tabular}{|c|c|c|c|c|c|c|}
\hline & $\mathbf{O}$ & $\mathbf{M}$ & STDEV & $\mid$ O/STDEV| & P Values & Comment \\
\hline EA -> EP & 0.321 & 0.324 & 0.033 & 9.575 & 0.000 & Supported \\
\hline
\end{tabular}

Note: Original Sample (O), Sample Mean (M), Standard Deviation (STDEV), T Statistics (|O/STDEV|)

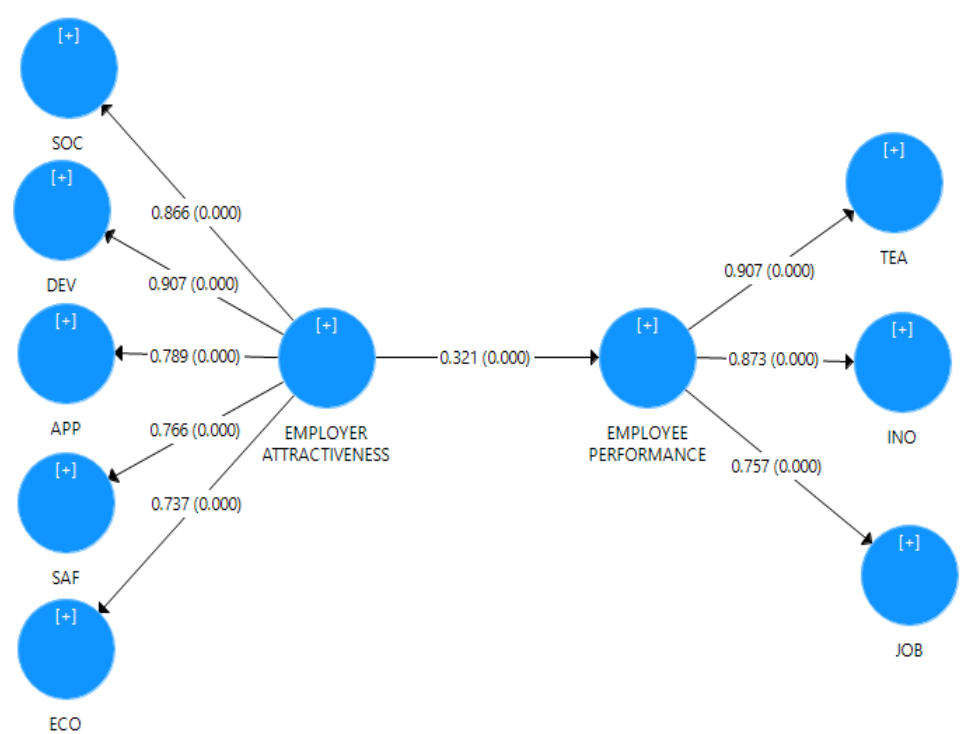

Figure 2. The research results. 


\section{Discussion}

That employer attractiveness positively impacts employee performance with impact coefficient $\beta=0.321$ (significance level $\mathrm{p}$-value $=0.000$ ) means that hypothesis $\mathrm{H} 2$ is supported. This result helps to add a new research direction of employer attractiveness because previous studies mainly focus on attracting potential candidates, especially on candidate recruitment' impact on work efficiency. Specifically, the previous employer attractiveness researchers pay more attention to potentially potential candidates (Sivertzen et al.; 2013 and Ha \& Luan, 2018) or employer attractiveness scale (Berthon et al., 2005). Therefore, the relationship between employer attractiveness and employee performance is affirmed in a new direction.

Theoretically, this result is consistent with the theory concerned. According to person-organisation (PO) fit theory (Kristof, 1996), there is harmony between the company and the employee by providing each other with the benefits and values that each side wishes to receive. The company will also provide employees with financial values (economy, physical and psychology as safety or opportunities like development and application). In contrast, employees will provide the company with their performance. The optimal relevance is that both satisfy both needs through the values mentioned above. Therefore, the positive relationship between employer attractiveness and employee performance is completely consistent with Person-Organization (PO) fit theory.

Compared to previous studies, this is a new research direction, so not many studies on this relationship for reference. The first study of Dabirian et al. (2019), analysing 15,000 IT employee reviews, identified eight values for IT employee evaluation to propose appropriate solutions for IT, company leaders, to use the employer brand effectively to attract and retain talent for improving human resource competitiveness or increasing the efficiency of employees. In another study, Slatten et al.(2019) found the role of organisational attractiveness as the powerful frontline in employees' perception of their internal market-oriented culture and turnover rate, engagement and service quality in hospitals; in which, organisational attractiveness has a positive impact on the service quality of nurses provided to patients. This research result is quite similar to that of Slatten et al. (2019). Pires (2020) studied Employer attractiveness and its impact on individual work performance moderated by national culture in multinational companies. With regression models, employer attractiveness dimensions (economic and application value) with a positive relationship with employee performance. To sum up, the results of the positive relationship between employer attractiveness and employee performance are rather relevant.

Practically, the positive effect of employer attractiveness on employee performance is relevant in practice. Firstly, factors related to the social work environment (supportive relationship, the collaboration between colleagues, the 
smooth coordination between superiors and subordinates, and friendliness in public work) will make employees more comfortable and think more positively to increase work motivation and positive impact on their work efficiency. Besides, with mutual support among colleagues, the work will go more smoothly and quickly because gathering collective strength will help the work more efficiency. Secondly, when the company focuses on employee development (DEV), employees can improve their competencies and solve problems effectively. Thirdly, when the company has an application value (APP), employees will be able to apply the knowledge they have learned in their real work to better the efficiency by being performed methodically and professionally.

Moreover, other colleagues also share new knowledge to improve their work and improve overall work efficiency. Fourthly, safety factor (SAF) contributes greatly to employee performance. When employees feel safe at work, they will create peace of mind and psychological stability to focus all their resources on the job. The ultimate value is economical (ECO): when the company provides a competitive salary and benefit, the employee will impact employee motivation so that employees focus entirely on the work and improve work efficiency greatly. In a nutshell, employer attractiveness positively impacts employee performance is completely consistent with the activities occurring in enterprise practices.

\section{Conclusion and Managerial Implications}

This study on the relationship between attracting employer attractiveness and employee performance in the Vietnamese context, confirm and adjust the employer attractiveness scale, and test the effect of employer attractiveness on employee performance is the new direction of employer attractiveness, emphasising the impact on current employees. The study uses qualitative and quantitative research methods to adjust and confirm the employer attractiveness and employee performance scales. The number of respondents to the survey is 937 from 37 enterprises and organisations in Vietnam. The result has developed a new factor for the employer attractiveness scale: safety factor (SAF). In summary, the research has confirmed the employer attractiveness scale including social value: SOC (6 items), developmental value: DEV (6 items), application value: APP (4 items), safety value: SAF (3 items) and economic value (3 items). The employee performance scale includes teamwork: TEA ( 8 items), innovator: INO (6 items) and job: JOB (3 items). Besides, the study tests research hypotheses and research models by using SPSS and PLS-SEM software. The analytical results show that standards on the measurement model and structural model (according to PLS-SEM) achieved criteria. The results also show that the factors of employer attractiveness and employee performance both positively impact its components. In particular, research has found that the positive effect of employer attractiveness on employee performance has a moderate degree of impact and $99 \%$ confidence. 
That employer attractiveness positively impacts employee performance directly with the impact coefficient at an average level of 0.321 confirms the influential role of employer attractiveness towards potential candidates and current employees. This result implies that managers can refer to more attractive business values to improve employee's work efficiency by studying and implementing several policies to apply employer attractiveness to increase employee performance. Firstly, managers should build a happy, fun and friendly working environment for social value and a good relationship among colleagues, between superiors and subordinates. It will help employees feel comfortable, happy and work more efficiently. Secondly, managers had better develop a diversified employee training and development program (career paths, inter-departmental experience experiences, succession planning, authorisation of work). Simultaneously, building employee development policy clearly and fairly helps all employees have the opportunity to develop. Thirdly, managers can enhance organisational learning model to promote internal training activities and enable employees to share their knowledge and experience with colleagues. It will help employees feel they have a valuable contribution to the organisation and a more meaningful life. Fourthly, the company should pay attention to its employees' safety and physical and mental safety. Managers increase the effective implementation of EHS (Environment - Health - Safety) strategy to have good remedial and preventive measures in safe operations. Finally, managers should pay attention to the effective implementation of salary, bonus and welfare policies for employees by surveying and referring to the salary levels and salary payment strategies in the market for appropriate adjustment to be competitive. To help improve employee performance, managers can promote synchronous social, developmental, application, safety, and economic factors.

\section{Limitations and further research}

This study focuses on respondents mostly from businesses operating in Vietnam. That it is impossible to cover all employees from other types of organisations (socio-political organisations, culture, media, education, non-government) will affect data generalisation criteria. Besides, this study uses the non-probability data collection method (convenient method), so the sample's accuracy and representativeness have some limitations. Another limitation of the study comes from the location of data collection: The study only collects survey questionnaires from respondents living in cities and provinces in the Southern region of Vietnam. There are differences in culture and customs between regions, leading to the difference in employee perceptions. This limitation will affect the research data accuracy, in particular, data generalisation. Finally, since the data collected from respondents is only available at a time, it is impossible to compare the change in perception of these respondents overtime series, leading to partly impacted research results. 
Therefore, further research can develop more precise and general data collection methods (using probability data collection method). Besides, study subjects can expand to non-business organisations (socio-political organisations, culture, journalism, education, non-government). For the geographical factor, it is possible to survey more broadly organisations in the Central and Northern regions of Vietnam for the more general research results. The study time may add some different times to compare and evaluate the change in employee's perception of employer attractiveness. Future studies may also expand some intermediate variables or moderator variables in the relationship between employer attractiveness and employee performance in terms of the research model. Besides the employee performance, the next research may discover other dimensions (employee satisfaction, commitment or loyalty) that employer attractiveness can impact.

\section{References}

Akinwande, M.O., Dikko, H.G. and Samson, A. (2015). Variance inflation factor: as a condition for the inclusion of suppressor variable(s) in regression analysis. Open Journal of Statistics, 5(7), 754-767.

Ali, A. Y. S., Ali, A. A., and Adan, A. A. (2013). Working conditions and employees' productivity in manufacturing companies in sub-Saharan African context: case of Somalia. Educational Research International, 2 (2), 67-78.

Ambler, T., and Barrow, S. (1996). The employer brand. Journal of brand management, 4 (3), 185-206.

Arachchige, B. J., and Robertson, A. (2013). Employer attractiveness: comparative perceptions of undergraduate and postgraduate students. Sri Lankan Journal of Human Resource Management, Vol 4 (1), , 33- 48.

Awan, A., and Tahir, M. (2015). Impact of working environment on employee's productivity: a case study of banks and insurance companies in Pakistan. European Journal of Business and Management, 7 (1), 329-345.

Baruch, Y. (2004). Transforming careers: from linear to multidirectional career paths: organizational and individual perspectives. Career development international, $9(1), 58-73$.

Baer, M., and Frese, M. (2003). Innovation is not enough: climates for initiative and psychological safety, process innovations, and firm performance. Journal of 
Organizational Behavior: The International Journal of Industrial, Occupational and Organizational Psychology and Behavior, 24 (1), , 45-68.

Bergstrom, A., Blumenthal, D., and Crothers, S. (2002). Why internal branding matters: the case of Saab. Corporate reputation review, 5 (2-3) , 133-142.

Berthon, P., Ewing, M. and Hah, L.L. (2005), Captivating company: dimensions of attractiveness in employer branding, International Journal of advertising, 24 (2), $151-172$.

Betaubun, K., Werang, B. R., and Rahail, E. B. (2015). The Impact of teachers' individual characteristics, teachers' work morale and teachers' job satisfaction on teachers' job performance at St. Francis Xavier $1 \& 2$ primary schools in Merauke City, Papua Province, Indonesia. Journal of Educational Policy and Entrepreneurial Research, 2 (4), 1-8.

Bhattacharyya, D. K.2007. Human resource research methods. Oxford University Press, New Delhi, India.

Biswas, M., and Suar, D. (2013). Which employees' values matter most in the creation of employer branding? Journal of marketing development and competitiveness, 7 (1), 93-102.

Blau, P. M. 1964. Exchange and power in social life. Transaction Publishers.

Bodderas, M., Cachelin, J. L., Maas, P., and Schlager, T. (2011). The influence of the employer brand on employee attitudes relevant for service branding: an empirical investigation. Journal of Service Marketing, 25 (7), 497-508.

Borman, W. G., and Motowidlo, S. J. 1997. Task perfor- mance and contextual performance: the meaning for personnel selection research. Human Performance, $10(2), 99-109$.

Brown, S. P., and Leigh, T. W. (1996). A new look at psychological climate and its relationship to job involvement, effort, and performance. Journal of applied psychology, 81 (4), 358 - 368.

Gampbell, J. P. 1990. Modeling the performance prediction problem in industrial and organizational psy- chology. In M. D. Dunnette and L. M. Hough (Eds.), Handbook of industrial and organizational psychology, 1 (2nd ed.): 687-732. Palo Alto, GA: Gonsulting Psychologists Press. 
Cassandro, M. H. (2008). Project manager, HR specialist, ONESTEPcompensation: Outline and denitions. HR Guide to the Internet. 2000. Access from: www.hrguide.com/data/G400.htm Compensation guide: A Manual on Compensation Practice \& theory.

Cohen, J. (1988). Statistical power analysis for the behavioral sciences (2nd ed.). Hillsdale, Erlbaum, NJ, New York.

Collins, C. J., and Stevens, C. K. (2002). The relationship between early recruitment-related activities and the application decisions of new labor-market entrants: a brand equity approach to recruitment. Journal of applied psychology, 87 (6), $1121-1133$.

Dabirian, A., Paschen, J., and Kietzmann, J. (2019). Employer branding: understanding employer attractiveness of IT companies. IT Professional, 21 (1) , 82-89.

Drucker, P. F.1998. Harvard business review on knowledge management. Harvard Business Press.

Drucker, P. F. (1999). Knowledge-worker productivity: the biggest challenge. California management review, 41 (2), 79-94.

Edmondson, A. (1999). Psychological safety and learning behavior in work teams. Administrative science quarterly, 44 (2), 350-383.

Edwards, J. R.1991. Person-job fit: a conceptual integration, literature review, and methodological critique. John Wiley \& Sons, Hoboken, New Jersey.

Farooq, M., and Khan, M. A. (2011). Impact of training and feedback on employee performance. Far east journal of psychology and business, Vol 5 (1), 23-33.

Gadibadi, C. (2020). Identifying dimensions of employer attractiveness in startups: the case of Swedish tech startups.

Gatewood, R. D., Gowan, M. A., and Lautenschlager, G. J. (1993). Corporate image, recruitment image and initial job choice decisions. Academy of management journal, Vol 36 (2), 414-427.

Gerbing, D. W., and Anderson, J. C. (1988). An updated paradigm for scale development incorporating unidimensionality and its assessment. Journal of marketing research, 25 (2), 186-192. 
Gomez-Mejia, L. R., and Balkin, D. B.1992. Compensation, organizational strategy, and firm performance. South-Western Pub, Gincinnati.

Gonzalez, M. (1999). Shifting the performance curve. Ivey Business Journal, July/August, 18-23.

Ha, N. M., and Luan, N. V. (2018). The effect of employers'attraction and social media on job application attention of senior students at Pharmaceutical Universities in Vietnam. International Journal of Business \& Society, 19 (2), 473 - 491.

Hair Jr, J. F., Sarstedt, M., Ringle, C. M., and Gudergan, S. P.2017. Advanced issues in partial least squares structural equation modeling. Sage publications, London.

Hlavsa, T., Urbancová, H., and Richter, P. (2015). Ways of human resource branding in czech agricultural companies. Scientia agriculturae bohemica, 46 (3), 112-120.

Harwiki, W. (2016). The impact of servant leadership on organization culture, organizational commitment, organizational citizenship behaviour (OCB) and employee performance in women cooperatives. Procedia-Social and Behavioral Sciences, 219, 283-290.

Hasibuan, Melayu S. P. 2008, Manajemen sumber daya manusia, Penerbit Bumi Aksara.șép, Jakarta, Indonesia

Hendry, C., and Jenkins, R. (1997). Psychological contracts and new deals. Human Resource Management Journal, 7 (1), 38 - 44.

Herman, R. E., and Gioia, J. L. (2001). Helping your organization become an employer of choice. Employment relations today. 28 (2), 63 - 78.

Hertzberg, F., Mausner, B. and Snyderman, B.B. 1959. The motivation to work. Wiley, New York, NY.

Geisser, S. (1974). A predictive approach to the random effect model. Biometrika, 61 (1), 101-107.

Gerbing, D. W., and Anderson, J. C. (1988). An updated paradigm for scale development incorporating unidimensionality and its assessment. Journal of marketing research, 25 (2), 186-192. 
Ivancevich, J.M. 2003. Human resource management. 9th edition New Delhi: Mc Graw-Hill Publishing, Boston.

Janssen, O. (2004). The barrier effect of conflict with superiors in the relationship between employee empowerment and organizational commitment. Work \& Stress, 18 (1), 56-65.

Jiang, T., and Iles, P. (2011). Employer-brand equity, organizational attractiveness and talent management in the Zhejiang private sector, China. Journal of Technology Management in China, 6 (1), 97-110.

Jurgensen, C. E. (1978). Job preferences (What makes a job good or bad?). Journal of Applied psychology, 63 (3), 267 - 276.

Kartikasari, R. D. (2017). Pengaruh work safety and health karyawan terhadap employee performance (Studi Pada Karyawan Bagian Produksi PT Surya Asbes Cement Group Malang). Jurnal Adminsitrasi Bisnis Universitas Brawijaya Malang, 44 (1).

Kaur, P., Sharma, S., Kaur, J., and Sharma, S. K. (2015). Using social media for employer branding and talent management: an experiential study. IUP Journal of Brand Management, 12 (2), 7 - 20.

Khoa, B.T., Huynh, L.T. and Nguyen, M.H, (2020), The relationship between perceived value and peer engagement in sharing economy: a case study of ridesharing services, Journal of System and Management Sciences, 10 (4), 149-72.

Khoa, B.T. "The role of mobile skillfulness and user innovation toward electronic wallet acceptance in the digital transformation era," International Conference on Information Technology Systems and Innovation (ICITSI), 2020, IEEE, pp. 30-37.

Khoa, B.T. and Thai, D.T. 2021, Capital structure and trade-off theory: evidence from Vietnam, The Journal of Asian Finance, Economics, and Business, 8 (1), 45 52.

Kianto, A., Vanhala, M., and Heilmann, P. (2016). The impact of knowledge management on job satisfaction. Journal of knowledge management, 20 (4), 621 636. 
Kristof, A. L. (1996). Person - organization fit: an integrative review of its conceptualizations, measurement, and implications. Personnel psychology, 49, (1), $1-49$.

Kivipõld, K. (2015). Organisational leadership capability-a mechanism of knowledge coordination for inducing innovative behaviour: a case study of Estonia service industries. Baltic Journal of Management, 10 (4), 478-496.

Łazorko, K. (2019). Work safety as an element of external employer branding strategy. Zeszyty Naukowe. Quality. Production. Improvement, Vol 11 (2), 16 - 25.

Lyu, X. (2016). Effect of organizational justice on work engagement with psychological safety as a mediator: evidence from China. Social Behavior and Personality: an international journal, 44 (8), 1359-1370.

Masakure, O. (2016). The effect of employee loyalty on wages. Journal of Economic Psychology, 56, 274-298.

May, D. R., Gilson, R. L., and Harter, L. M. (2004). The psychological conditions of meaningfulness, safety and availability and the engagement of the human spirit at work. Journal of occupational and organizational psychology, 77 (1), 11-37.

McGuire, D., and McLaren, L. (2009). The impact of physical environment on employee commitment in call centres: the mediating role of employee well-being. Team Performance Management, 15 (1), 35-48.

Milkovich, G. T., and Newman, J. M.1999. Compensation. Irwin, Boston.

Muchinsky, P. M., and Monahan, C. J. (1987). What is person-environment congruence? Supplementary versus complementary models of fit. Journal of vocational behavior, 31 (3), 268-277.

Muzaffar, M. U., Salamat, S. H. and Ali, M. M. (2012). Impact of trainings on employees outcome in IT Sector Pakistan. Global Journal of Management and Business Research, 12 (6), 20-26.

Newell, H., and Dopson, S. (1996). Muddle in the middle: organizational restructuring and middle management careers. Personnel Review, 25 (4), 4-20.

Nguyen, H. M., and Ngo, T. T. (2020). Psychological capital, organizational commitment and job performance: a case in Vietnam. The Journal of Asian Finance, Economics, and Business, 7 (5), 269-278. 
Nguyen, H. M., Nguyen, C., Ngo, T. T., and Nguyen, L. V. (2019). The effects of job crafting on work engagement and work performance: a study of vietnamese commercial banks. The Journal of Asian Finance, Economics, and Business, 6 (2), 189-201.

Nguyen, M.T. and Khoa, B.T. 2020, Improving the competitiveness of exporting enterprises: a case of Kien Giang Province in Vietnam, The Journal of Asian Finance, Economics and Business, 7 (6), 495-508.

Nonaka, I. (1994). A dynamic theory of organizational knowledge creation. Organization science, 5 (1), 14-37.

Ojokuku, R. M., and Sajuyigbe, A. S. (2009). Effect of pay satisfaction dimensions on job performance in selected tertiary institutions in Osun State, Nigeria. African Journal Institute and Development (AJID), 4 (2), 86-95.

Organ, D. W. (1988). A restatement of the satisfaction-performance hypothesis. Journal of management, 14 (4), 547-557.

Peretomode, V. F., and Peretomode, O. 2005. Human resources management: principles, policies and practices. Onosomegbowho Ogbinaka Publishers.

Permanasari, J.E. (2014). Analisis Pengaruh Kesehatan Dan Keselamatan Kerja (K3) Terhadap Performance Dengan JOB SATISFACTION Sebagai Variabel Interventing. Skripsi Fakultas Ekonomika dan Bisnis Universitas Diponegoro.

Pingle, S. S., and Sharma, A. (2013). External employer attractiveness: a study of management students in India. Journal of Contemporary Management Research, 7 (1), $78-95$.

Pires, M. C. (2020). Employer attractiveness and its impact on individual work perfomance moderated by national culture (Doctoral dissertation), ISPA- Instituto Universitário - Ciências Psicológicas, Sociais e da Vida, Portugal.

Reis, G. G., and Braga, B. M. (2016). Employer attractiveness from a generational perspective: implications for employer branding. Revista de Administração (São Paulo), 51 (1), 103-116.

Roy, S. K. (2008). Identifying the dimensions of attractiveness of an employer brand in the Indian context. South Asian Journal of Management, 15 (4), 110 - 130. 
Sajuyigbe, A. S., Olaoye, B. O., and Adeyemi, M. A. (2013). Impact of reward on employees performance in a selected manufacturing companies in Ibadan, Oyo State, Nigeria. International Journal of Arts and Commerce, 2 (2), 27-32.

Schein, E. H.1980. Organizational psychology (3rd ed.). Englewood Gliffs, Prentice-Hall, New York.

Sivertzen, A. M., Nilsen, E. R., and Olafsen, A. H. (2013). Employer branding: employer attractiveness and the use of social media. Journal of Product \& Brand Management, 22 (7), 473-483.

Slåtten, T., Lien, G., and Svenkerud, P. J. (2019). The role of organizational attractiveness in an internal market-oriented culture (IMOC): a study of hospital frontline employees. BMC health services research, 19 (1), 1-15.

Sok, P., and O'Cass, A. (2011). Achieving superior innovation-based performance outcomes in SMEs through innovation resource-capability complementarity. Industrial Marketing Management, 40 (8), 1285-1293.

Soutar, G. N., and Clarke, A. W. (1983). Examining business students' career preferences: a perceptual space approach. Journal of Vocational Behavior, 23 (1), 11-21.

Spence, M. (1973). Job market signaling. Quarterly Journal of Economics, 87 (3), 355-374.

Stevens, M. J., and Campion, M. A. (1994). The knowledge, skill, and ability requirements for teamwork: implications for human resource management. Journal of management, 20 (2), 503-530.

Stone, M. (1974). Cross-validation and multinomial prediction. Biometrika, 61 (3), 509-515.

Thamhain, H. J. (2003). Managing innovative R\&D teams. $R \& d$ Management, 33 (3), 297-311.

Tseng, F. C., and Fan, Y. J. (2011). Exploring the influence of organizational ethical climate on knowledge management. Journal of business ethics, 101 (2), 325-342.

Tumasjan, A., Strobel, M., and Welpe, I. M. (2011). Employer brand building for start-ups: which job attributes do employees value most?. Zeitschrift für Betriebswirtschaft, 81 (6), 111-136. 
Tziner, A. (1987). Congruency issue retested using Fineman's achievement climate notion. Journal of Social Behavior and Personality, 2 (1), 63 - 78.

Van Maanen, J., and Schein, E. H. 1979. Toward a theory of organizational socialization. In B. M. Staw (Ed.), research in organizational behavior, 1: 209-264. Greenwich, GT: JAI Press.

Wally, O. 1989. Corporate identity. Thames and Hudson, London

Welbourne, T. M., and Cable, D. M. (1995). Group incentives and pay satisfaction: understanding the relationship through an identity theory perspective. Human Relations, 48 (6), 711-726.

Welbourne, T. M., Johnson, D. E., and Erez, A. (1998). The role-based performance scale: validity analysis of a theory-based measure. Academy of management journal, $41(5), 540-555$.

Welbourne, T. M., and Mejia, L. R. G. (1995). Gainsharing: a critical review and a future research agenda. Journal of management, 21 (3), 559-609.

West, M. A., and Anderson, N. R. (1996). Innovation in top management teams. Journal of Applied psychology, 81 (6), 680. 